\title{
Binding and Release of Cations by Sarcoplasmic Reticulum before and after Removal of Lipid
}

\author{
Arsélio P. Carvalho \\ Institute for Muscle Disease, New York, and Laboratório Zoológico, Universidade de Coimbra
}

(Received October 29, 1971/January 17, 1972)

1. The $\mathrm{Ca}^{2+}$ bound actively in the presence of ATP by sarcoplasmic reticulum isolated from rabbit skeletal muscle is released by $\mathrm{Zn}^{2+}$ (or $\mathrm{Cd}^{2+}$ ) as well as by phospholipases $\mathrm{A}$ or $\mathrm{C}$ and by trypsin. Zinc ions also release $\mathrm{Mg}^{2+}$ and are taken up passively by the reticulum membranes, whereas phospholipases $\mathrm{A}$ and $\mathrm{C}$ and trypsin release only the actively bound $\mathrm{Ca}^{2+}$.

2. Phospholipase $A$, and to a smaller extent phospholipase $C$ and trypsin, increase the passive eation-binding capacity of reticulum. Thus, concurrently with the loss of selectively bound $\mathrm{Ca}^{2+}$ caused by these agents, there is an increase in the passively bound $\mathrm{Mg}^{2+}$. The increase in the passive eation-binding capacity of reticulum induced by phospholipase depends on the presence of the splitting products of phospholipids, since their removal when digested reticulum is washed with a $2.5 \%$ albumin solution decreases the binding capacity to about $50 \%$ of the original value.

3. When $\mathrm{Ca}^{2+}, \mathrm{Mg}^{2+}$ or $\mathrm{Sr}^{2+}$ is bound passively by reticulum, the ratio of $\mathrm{H}^{+}$released to either of these divalent cations bound, expressed in terms of nequiv $\mathrm{H}^{+}$released per nequiv divalent cation bound is about 1.0 , but when $\mathrm{Zn}^{2+}$ is taken up, the ratio $\mathrm{H}^{+} / \mathrm{Zn}^{2+}$ is only about 0.5 , which suggests that some of the $\mathrm{Zn}^{2+}$ is bound at sites that do not release $\mathrm{H}^{+}$or bind $\mathrm{Ca}^{2+}$.

4. After lipid extraction with $90 \%$ acetone, the cation-binding capacity and $\mathrm{H}^{+}$release are decreased to about $40 \%$ of the original values. This effect is particularly evident between $\mathrm{pH}$ values of about 6.0 and 8.0. The apparent passive $\mathrm{Ca}^{2+}$-binding affinity is not affected by the lipid removal.

A fundamental problem in $\mathrm{Ca}^{2+}$ storage by sarcoplasmic reticulum is whether $\mathrm{Ca}^{2+}$ uptake involves mainly a transmembrane transport with accumulation of free $\mathrm{Ca}^{2+}$ within the vesicles $[1-3]$ or whether the accumulated $\mathrm{Ca}^{2+}$ is stored bound to the reticular membranes $[4,5]$. The early studies in this field dealt with the accumulation of $\mathrm{Ca}^{2+}$ by the reticulum on the explit or implicit assumption that all $\mathrm{Ca}^{2+}$ is transported across the membranes and retained intravesicularly as free $\mathrm{Ca}^{2+}[1,2]$. More recently, we presented evidence that the bulk of the $\mathrm{Ca}^{2+}$ accumulated in the absence of precipitating agents remains bound to the membrane [4]. Therefore, in studying the mechanism of release of the $\mathrm{Ca}^{2+}$ which triggers the activity of the contractile elements of the muscle cell, the prime event in the release of accumulated $\mathrm{Ca}^{2+}$ may be the dissociation of $\mathrm{Ca}^{2+}$ from the reticular membranes rather than an increase in the permeability of the vesicular membranes to $\mathrm{Ca}^{2+}$ as suggested by other investigators $[6-10]$.

Enzymes. Phospholipase A (EC 3.1.1.4); phospholipase C (EC 3.1.4.3); trypsin (EC 3.4.4.4).
Experimentally it is difficult to distinguish between the two mechanisms of $\mathrm{Ca}^{2+}$ release since a particular agent which augments the rate of liberation of $\mathrm{Ca}^{2+}$ by reticulum could act conceivably by either or both mechanisms. Nevertheless, the concept that substances which increase the release of $\mathrm{Ca}^{2+}$ by reticulum do so by increasing the permeability of the membranes is currently more acceptable since most studies have been performed in the presence of oxalate which retains the $\mathrm{Ca}^{2+}$ intravesicularly in insoluble form. It is unlikely that the substances tested (e.g. phospholipase, trypsin, and fatty acids) would alter significantly the solubility constant of calcium oxalate, so that it appears reasonable to assume that these substances alter the membrane permeability. However, such interaction with the membrane might not be limited to modifying its permeability properties; the caticn binding groups of the membranes and their affinity and capacity for $\mathrm{Ca}^{2+}$ may also be affected.

In the absence of precipitating agents, a more physiological state, we find that at least $80 \%$ of the 
$\mathrm{Ca}^{2+}$ accumulated is adsorbed to the reticular membranes [4]. Therefore, it is of interest to determine whether agents which release $\mathrm{Ca}^{2+}$ from reticulum have a direct effect on the ability of the membrane components to bind $\mathrm{Ca}^{2+}$. This study shows that phospholipase $A$ and trypsin affect the binding sites of the reticular membranes. Either enzyme causes the loss of $\mathrm{Ca}^{2+}$-binding selectivity, but increases the total passive cation-binding capacity of the membranes. Membranes which have lost most of their phospholipids have a $\mathrm{Ca}^{2+}$-binding capacity less than $50 \%$ of the normal value. Furthermore, $\mathrm{H}^{+}$is released concomitantly with the passive binding of the cations studied (e.g., $\mathrm{Ca}^{2+}, \mathrm{Mg}^{2+}, \mathrm{Sr}^{2+}, \mathrm{Zn}^{2+}$ and $\mathrm{K}^{+}$), which indicates that the binding occurs at anionic sites.

\section{METHODS}

\section{Preparation of Biological Material}

Sarcoplasmic reticulum was isolated from rabbit skeletal muscle as described previously [11] except that when the presence of $\mathrm{KCl}$ and buffer were to be avoided the last wash was carried out with $0.25 \mathrm{M}$ sucrose and the reticulum was finally resuspended in $0.25 \mathrm{M}$ sucrose. Extractions of the phospholipids were performed with $90 \%$ acetone and ammonia as described by Fleischer et al. [12].

\section{Measurements of the Binding of Cations by Sarcoplasmic Reticulum}

The uptake of calcium by sarcoplasmic reticulum was measured either after ATP added to the medium had been hydrolyzed and the reticulum had been washed with $0.25 \mathrm{M}$ sucrose, or the measurements were made in reticulum which had taken up $\mathrm{Ca}^{2+}$ passively, i.e. in the absence of ATP.

When ATP was used to "load" the reticulum with $\mathrm{Ca}^{2+}, 0.2 \mathrm{mM}$ of the nucleotide were added to the suspension and the hydrolysis of the ATP was allowed to proceed. It was found that at the concentrations of reticulum normally employed $(1.0-1.2 \mathrm{mg} / \mathrm{ml}$ medium) essentially all ATP was hydrolysed in about $10 \mathrm{~min}$. The medium employed for this "active" uptake of $\mathrm{Ca}^{2+}$ contained imidazole, $20 \mathrm{mM}$ at pH 7.0; $\mathrm{MgCl}_{2}, 5 \mathrm{mM}$; $\mathrm{CaCl}_{2}, 0.15 \mathrm{mM}$; sarcoplasmic reticulum, $1.0-1.2 \mathrm{mg} / \mathrm{ml}$. The reaction was initiated at $22{ }^{\circ} \mathrm{C}$ by the addition of ATP to a final concentration of $0.2 \mathrm{mM}$. At various periods after the addition of ATP, $10 \mathrm{ml}$ portions of the suspension were centrifuged at $105000 \times g$ for $30 \mathrm{~min}$. The pellets were resuspended in $10 \mathrm{ml} 0.25 \mathrm{M}$ sucrose at $0-4{ }^{\circ} \mathrm{C}$ and centrifuged as before. The pellets and internal walls of the tubes were then rinsed with distilled water and finally were resuspended in $6.5 \mathrm{ml}$ of water. Analyses for the various cations and for protein were then performed on this suspension. The concentration

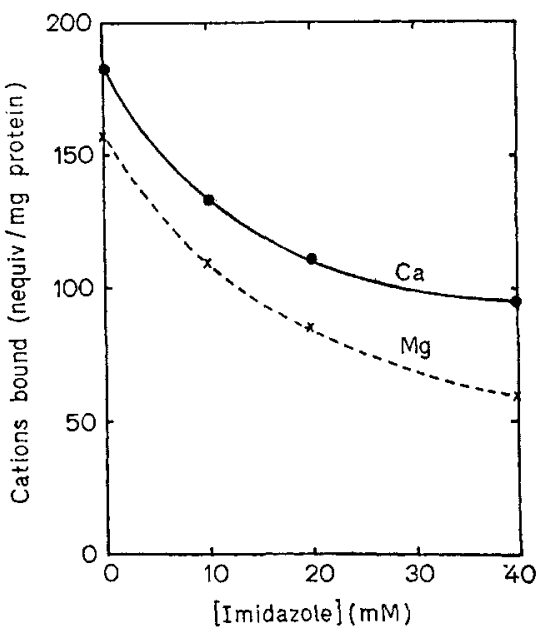

Fig.1. Effect of imidazole at pH 7.0 on the passive uptake of $\mathrm{Ca}^{2+}$ and $\mathrm{Mg}^{2+}$ by sarcoplasmic reticulum. The medium contained $10 \mathrm{ml}$ of imidazole solution maintained at $\mathrm{pH} 7.0$ with a Radiometer $\mathrm{pH}$ stat and $200 \mu \mathrm{M}$ each of $\mathrm{CaCl}_{2}$ and $\mathrm{MgCl}_{2} \cdot \bullet, \mathrm{Ca}^{2+} ; \times, \mathrm{Mg}^{2+}$

of the various cations was measured by atomic absorption spectrophotometry as described previously [4].

It was previously shown that the cations retained by the sarcoplasmic reticulum under these conditions are bound at binding sites of the membranes and that the $\mathrm{Ca}^{2+}$ uptake releases an equivalent amount of $\mathrm{Mg}^{2+}$ from the membranes so that the total amount of cations retained by the membranes is constant [4]. Therefore, this system is ideal to study the effect of the drugs and other substances that may normally affect the binding of $\mathrm{Ca}^{2+}$ (and other cations) by the reticulum. Furthermore, it permits us to distinguish between the effects of the various substances on $\mathrm{Ca}^{2+}$ fluxes across the reticular membranes which have been studies by others $[6-9,13-15]$, and the direct effect of the substances on the release of bound $\mathrm{Ca}^{2+}$ or other cations associated with the membranes. Since the ATP added is hydrolysed within $10 \mathrm{~min}$, any $\mathrm{Ca}^{2+}$ transport ceases at this time, and, thus, the effects studied are strictly on the release of the bound cations retained under the condition of our experiments.

The passive binding of cations was studied at $22{ }^{\circ} \mathrm{C}$ in a medium containing $5 \mathrm{mg}$ of reticulum protein suspended in $10 \mathrm{ml}$ of $0.25 \mathrm{M}$ sucrose. The $\mathrm{pH}$ of the medium was controlled with a Radiometer $\mathrm{pH}$ stat in the absence of added buffer. Imidazole, which commonly has been used as a buffer, competes with the reticulum for the $\mathrm{Ca}^{2+}$ and $\mathrm{Mg}^{2+}$ in the medium, and, thus, the apparent binding affinity of the reticulum for $\mathrm{Ca}^{2+}$ is much depressed in a medium containing imidazole (Fig.1). Therefore, the experiments on the passive binding of cations by reticulum were 
carried out in the absence of imidazole. After adjusting the $\mathrm{pH}$ to the desired value, the cations were added with a syringe microburet and the liberation of $\mathrm{H}^{+}$ from the reticulum induced by the cations was calculated from the $\mathrm{KOH}$ needed to neutralize the $\mathrm{H}^{+}$ liberated. The total volume of solution of cations $(100 \mathrm{mM})$ plus solution of $\mathrm{KOH}(10 \mathrm{mM})$ usually did not exceed $200-300 \mu \mathrm{l}$.

The suspensions of the reticulum were equilibrated for $10 \mathrm{~min}$ and then were centrifuged at $105000 \times g$ for $30 \mathrm{~min}$, the supernatants were collected, the pellets and internal walls of the tubes were rinsed with distilled water, and the pellets were resuspended in $6.5 \mathrm{ml}$ water. Analysis for cations and protein were then performed on this suspension as in the case of active described above.

The concentrations of free cations and the $\mathrm{pH}$ were determined in the supernatant solutions and corrections for the amount in the trapped fluid of the pellet were made. These corrections usually were negligible since the amount of cations in the trapped fluid represented a negligible percentage of the total cations bound to the protein of the pellets.

\section{Determination of the Effect of Phospholipase, Trypsin, Zinc and Cadmium on the Release of Cations by Sarcoplasmic Reticulum}

These studies are those whose results are summarized in Fig.3-5. The enzymes or the heavy metal cations $\left(\mathrm{Zn}^{2+}\right.$ or $\left.\mathrm{Cd}^{2+}\right)$ were added to the reticulum suspensions after $\mathrm{Ca}^{2+}$ had been taken up actively in the presence of ATP and all the ATP had been hydrolyzed. Therefore, any loss of $\mathrm{Ca}^{2+}$ induced by the test agents under these conditions, reflected an effect of the agents on the release process. The measurements of the $\mathrm{Ca}^{2+}$ retained by the reticulum before or after the addition of the test agents were made after the reticulum had been centrifuged and washed once with $10 \mathrm{ml} 0.25 \mathrm{M}$ sucrose. Under these experimental conditions the $\mathrm{Ca}^{2+}$ retained is in the bound form. This binding occurs at the expense of $\mathrm{Mg}^{2+}, \mathrm{K}^{+}$or $\mathrm{H}^{+}$from the binding sites of the membranes [4].

For the experiments whose results are reported in Fig. 5, the reticulum was pretreated with phospholipase $A$ or with trypsin in a medium containing $0.25 \mathrm{M}$ sucrose at a $\mathrm{pH}$ value maintained at 7.0 by a Radiometer $\mathrm{pH}$ stat. The ratio of phospholipase A or trypsin to reticular protein was about 1:100 and the reaction was carried out for $60 \mathrm{~min}$. The phospholipase $A$ is much less active in this medium than it is when $\mathrm{Ca}^{2+}$ is present, but even is the absence of $\mathrm{Ca}^{2+}$ we could obtain hydrolyses of about $75 \%$ of the phospholipids of the membranes as estimated from their phosphorus content before and after hydrolyses and washing with $2.5 \%$ albumin solution (Table 1 ). After treatment with the enzymes the reticulum was

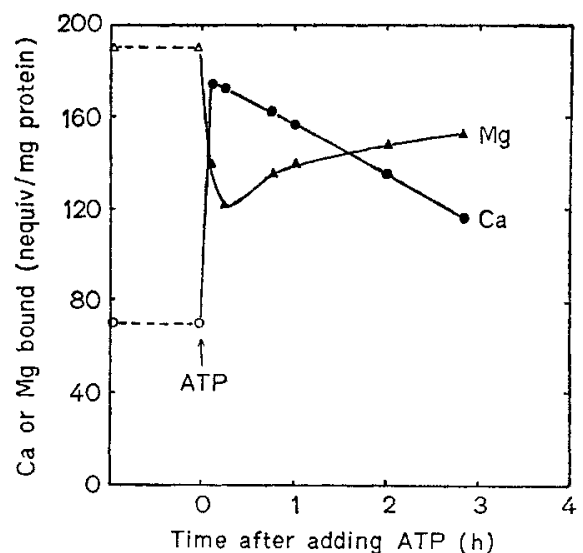

Fig. 2. Exchange of $\mathrm{Ca}^{2+}$ for $\mathrm{Mg}^{2+}$ and vice-versa during active uptake and release of $\mathrm{Ca}^{2+}$ by sarcoplasmic reticulum. The reticulum $(2 \mathrm{mg} / \mathrm{ml})$ was placed in medium containing $20 \mathrm{mM}$ imidazole at $\mathrm{pH} 7.0,5 \mathrm{mM} \mathrm{MgCl}, 20 \mathrm{mM} \mathrm{KCl}$, and $0.15 \mathrm{mM}$ $\mathrm{CaCl}_{2}$ and allowed to equilibrate for $10 \mathrm{~min}$. Before the addition of $0.2 \mathrm{mM}$ ATP (open symbols), $10 \mathrm{ml}$ samples were taken and centrifuged at $105000 \times g$ for $30 \mathrm{~min}$ and the pellets were washed once with $0.25 \mathrm{M}$ sucrose. The bound $\mathrm{Ca}^{2+}$ and $\mathrm{Mg}^{2+}$ retained under these conditions is represented by the points at zero time at which point ATP was added. The bound cations were again measured as before at various times after the addition of ATP (filled symbols). In each case, the reticulum was washed with $0.25 \mathrm{M}$ sucrose at $0-4{ }^{\circ} \mathrm{C}$ to remove free cations before measuring the cations retained. All ATP added was hydrolysed within $10 \mathrm{~min}$. $\mathrm{A}, \mathrm{Mg}^{2+}$; $\mathrm{Ca}^{2+}$

resuspended in $0.25 \mathrm{M}$ sucrose (1 $\mathrm{mg}$ protein $/ \mathrm{ml}$ ) at $0-4{ }^{\circ} \mathrm{C}$ and centrifuged. The pellets were collected and resuspended in $0.25 \mathrm{M}$ sucrose at $5 \mathrm{mg}$ protein $/ \mathrm{ml}$ before the material was used in the experiments.

\section{RESULTS}

Effect of $\mathrm{Zn}^{2+}$ and $C d^{2+}$ on the Release of Ca Bound Actively by Sarcoplasmic Reticulum

As $\mathrm{Ca}^{2+}$ is bound "actively" by sarcoplasmic reticulum it replaces $\mathrm{Mg}^{2+}$ and other cations previously bound to the membranes [4]. Fig. 2 shows the exchange of $\mathrm{Ca}^{2+}$ for $\mathrm{Mg}^{2+}$, and that a large fraction of the bound $\mathrm{Ca}^{2+}$ is retained by the membranes for periods up to three hours after all ATP has been hydrolysed. When the loaded reticulum was left in the original medium which contained $5 \mathrm{mM} \mathrm{Mg}^{2+}$ there was a gradual exchange of the $\mathrm{Ca}^{2+}$ bound for $\mathrm{Mg}^{2+}$ from the medium (Fig.2). An exchange of $\mathrm{Ca}^{2+}$ for bound cations other than $\mathrm{Mg}^{2+}$ (i.e. $\mathrm{K}^{+}$and $\mathrm{H}^{+}$) also occurs, but we did not measure this exchange in the experimental results reported here, since $\mathrm{Mg}^{2+}$ was the predominant bound cation before the uptake of $\mathrm{Ca}^{2+}$. Some exchange of $\mathrm{Ca}^{2+}$ with the other bound cation accounts for the deviation from the nearly $1: 1$ exchange between $\mathrm{Ca}^{2+}$ and $\mathrm{Mg}^{2+}$ observed previously [4]. 


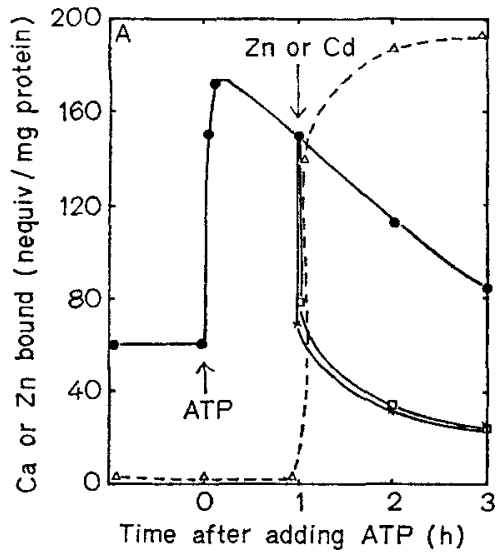

Fig. 3. Release of bound $\mathrm{Ca}^{2+}$ from sarcoplasmic reticulum by $\mathrm{Zn}^{2+}$ and $\mathrm{Cd}^{2+}$. The experimental conditions are identical to those described in the legend of Fig.2, except that at $1 \mathrm{~h}$ after the addition of $0.2 \mathrm{mM}$ ATP, $0.125 \mathrm{mM} \mathrm{ZnCl}_{2}$ or $\mathrm{CdCl}_{2}$ were added to the medium. Samples were then centrifuged at various times, the pellets were washed with $10 \mathrm{ml} 0.25 \mathrm{M}$

Since the $\mathrm{Ca}^{2+}$ and $\mathrm{Mg}^{2+}$ remain bound for relatively long periods after all ATP is removed from the medium, it is possible to study the effect of various agents on the release of these cations. Fig. $3 \mathrm{~A}$ and $\mathrm{B}$ shows the effect of $0.125 \mathrm{mM} \mathrm{Zn} \mathrm{Zn}^{2+}$ or $\mathrm{Cd}^{2+}$ added to reticulum which had been actively loaded with $\mathrm{Ca}^{2+}$ by adding $0.2 \mathrm{mM}$ ATP. Fig. $3 \mathrm{~A}$ depicts the $\mathrm{Ca}^{2+}$ content of the reticulum whereas Fig. 3B depicts its $\mathrm{Mg}^{2+}$ content. It should be emphasized that, under the condition of the experiments, the cations retained by the reticulum are in fact bound at binding sites, as was established in other detailed work reported previously ]4].

Zinc on cadmium ions greatly increase the rate of release of bound $\mathrm{Ca}^{2+}$ by the reticular membranes. At the moment that $\mathrm{Zn}^{2+}$ or $\mathrm{Cd}^{2+}$ was added, the reticulum contained about 150 nequiv $\mathrm{Ca}^{2+}$ bound per mg of protein, whereas immediately after the addition of the heavy metal cations the $\mathrm{Ca}^{2+}$ content of the reticulum dropped to about 60 , and subsequently to 30 , nequiv/mg protein (Fig. $3 \mathrm{~A}$ ). The bound $\mathrm{Mg}^{2+}$ was also decreased from 160 to about 80 nequiv/ $\mathrm{mg}$ protein (Fig. 3 B). Concurrently, the reticulum membranes bound about 190 nequiv $\mathrm{Zn}^{2+} / \mathrm{mg}$ protein so that the displacement of bound $\mathrm{Ca}^{2+}$ plus $\mathrm{Mg}^{2+}$ was nearly equal to the uptake of $\mathrm{Zn}^{2+}$. However, it will be shown in another section that, at least under certain conditions, $\mathrm{Zn}^{2+}$ also binds to sites that normally do not bind $\mathrm{Ca}^{2+}$ or $\mathrm{Mg}^{2+}$.

\section{Effects of Trypsin and Phospholipases on the Release of $\mathrm{Ca}^{2+}$ Bound Actively by Sarcoplasmic Reticulum}

The experiments reported here show that trypsin, or phospholipases $\mathrm{A}$ or $\mathrm{C}$, decrease the bound $\mathrm{Ca}^{2+}$ retained by the membranes of the reticulum after it

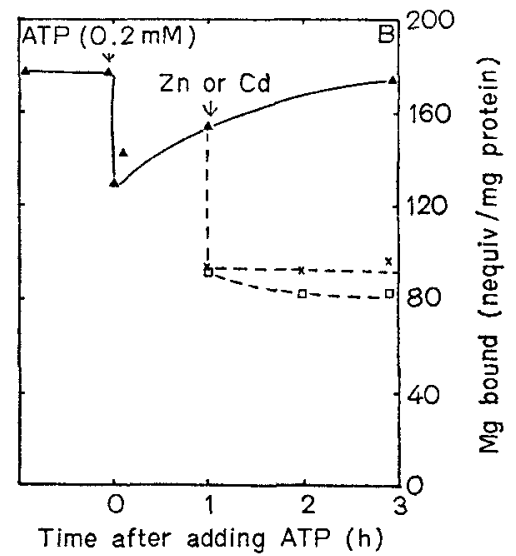

sucrose at $0-4{ }^{\circ} \mathrm{C}$ and the bound cations were measured. (A) Effect of $\mathrm{Zn}^{2+}$ or $\mathrm{Cd}^{2+}$ on $\mathrm{Ca}^{2+}$ binding. $\triangle, \mathrm{Zn}^{2+}$ bound; ๑, $\mathrm{Ca}^{2+}$ bound; $\square, \mathrm{Ca}^{2+}$ bound after addition of $\mathrm{Zn}^{2+} ; \times, \mathrm{Ca}^{2+}$ bound after addition of $\mathrm{Cd}^{2+}$. (B) Effect on $\mathrm{Mg}^{2+}$ binding, $\Lambda, \mathrm{Mg}^{2+}$ bound; $\square, \mathrm{Mg}^{2+}$ bound after addition of $\mathrm{Zn}^{2+}$; $\times$, $\mathrm{Mg}^{2+}$ bound after addition of $\mathrm{Cd}^{2+}$

has been loaded actively in the presence of ATP (Fig. 4 A and B). The enzymes were added $20 \mathrm{~min}$ after the ATP, so that sufficient time was allowed for complete hydrolysis of the nucleotide before adding the enzymes. Either of the phospholipases or trypsin decreased the $\mathrm{Ca}^{2+}$ bound to a value about equal to that observed before the addition of ATP (Fig. 4A). The surprising observation made in these studies was that the $\mathrm{Mg}^{2+}$ bound by the reticulum was very much increased by the enzymes; in the case of phospholipase $\mathrm{A}$, the increase in $\mathrm{Mg}^{2+}$ binding was from about 90 to 180 nequiv/mg protein (Fig. 4B). Trypsin consistently had a qualitatively similar effect on the $\mathrm{Mg}^{2+}$ binding, and phospholipase $\mathrm{C}$, which reduced the $\mathrm{Ca}^{2+}$ binding, had only a small effect on the $\mathrm{Mg}^{2+}$ binding (Fig.4B).

Considering that in these experiments we measured only the cations bound to the membranes, the results indicate that the enzymes tested have essentially two effects. Firstly, the specificity of the $\mathrm{Ca}^{2+}$ retention induced by ATP is destroyed which results in the loss of the bound $\mathrm{Ca}^{2+}$ which is displaced competitively by the $\mathrm{Mg}^{2+}$. Whether this represents an increased permeability of the membrane to $\mathrm{Ca}^{2+}$ or a direct effect of the enzymes on the binding sites is discussed in another section. Secondly, phospho. lipase $\mathrm{A}$ or trypsin, in addition to destroying the specificity of the membranes for $\mathrm{Ca}^{2+}$, also increases the number of binding sites accessible to the cations in the medium. Since in these experiments the cations in the medium are mostly $\mathrm{Mg}^{2+}(3-5 \mathrm{mM})$, it is the binding of this cation which is observed to increase, but we have evidence that $\mathrm{Ca}^{2+}$ also has access to these binding sites. This is demonstrated by the results of the experiments reported in the next section. 


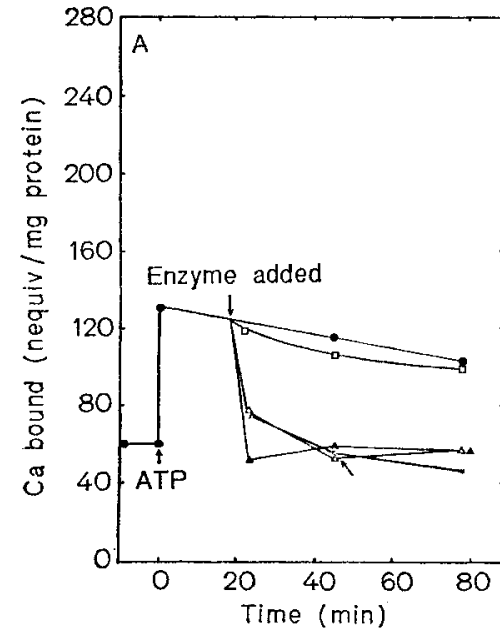

Fig.4. Release of bound $\mathrm{Ca}^{2+}$ by phospholipases $A$ and $C$ by trypsin. The experimental conditions were identical to those described in legend of Fig. 2, except that at $20 \mathrm{~min}$ after the addition of $0.2 \mathrm{mM}$ ATP, phospholipases $\mathrm{A}$ and $\mathrm{C}$, and trypsin or trypsin plus trypsin inhibitor were added to the medium. Phospholipase A or trypsin present was $1 \mathrm{mg} / 60 \mathrm{mg}$ reticulum protein, phospholipase $\mathrm{C}, 1 \mathrm{mg} / 10 \mathrm{mg}$ and trypsin inhibitor, $2 \mathrm{mg} / \mathrm{mg}$ trypsin. Samples were then centrifuged at various

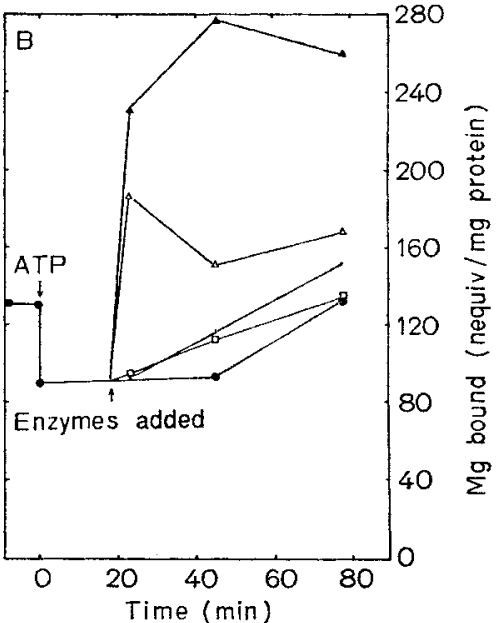

times, the pellets were washed with $10 \mathrm{ml}$ of $0.25 \mathrm{M}$ sucrose at $0-4^{\circ} \mathrm{C}$, and the bound cations were measured. (A) Effects of the enzymes on $\mathrm{Ca}^{2+}$ binding; $\bullet, \mathrm{Ca}^{2+}$ bound; $\square$, with trypsin and trypsin inhibitor; $\Delta$, with trypsin; $\boldsymbol{\Lambda}$, phospholipase $\mathrm{A} ; \mathrm{x}$, phospholipase $\mathrm{C}$. (B) Effect on $\mathrm{Mg}^{2+}$ binding; $\bullet \mathrm{Mg}^{2+}$ bound; $\square$, with trypsin and trypsin inhibitor; $\triangle$, with trypsin; $\boldsymbol{\Delta}$, with phospholipase $A ; \times$, with phospholipase C

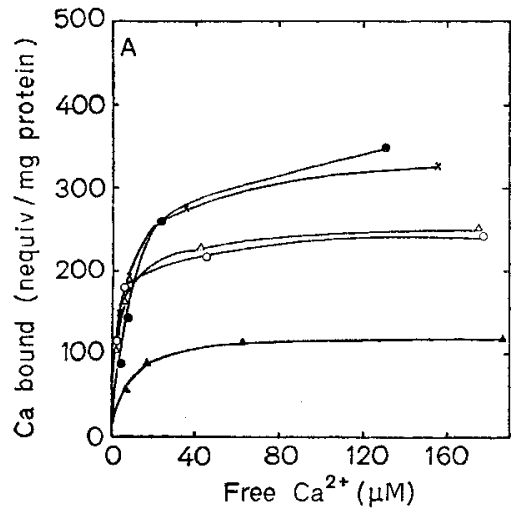

Fig. 5. The effect of pretreatment of sarcoplasmic reticulum with phospholipase $A$ or trypsin on the passive binding of $\mathrm{Ca}^{2+}$ and the release of $\mathrm{H}^{+}$. Sareoplasmic reticulum was treated with phospholipase A or trypsin as described in the text. In some cases the reticulum treated with phospholipase was washed with $2.5 \%$ albumin solution. Before the reticulum was used in these studies it was washed with $0.25 \mathrm{mM}$ sucrose $(1 \mathrm{mg}$

\section{Effects of Trypsin or Phospholipase A}

on the Passive Binding of $\mathrm{Ca}^{2+}, \mathrm{Mg}^{2+}$ and $\mathrm{Zn}^{2+}$ by Sarcoplasmic Reticulum

In these experiments we tested whether trypsin or phospholipase actually increases the number of binding sites of the reticulum membranes as postulated above. The passive uptake of $\mathrm{Ca}^{2+}$ and the consequent release of $\mathrm{H}^{+}$was measured at a $\mathrm{pH}$ value of 7.0 in a $0.25 \mathrm{M}$ sucrose medium in the absence of ATP. Fig.5 A and B depict the results obtained and

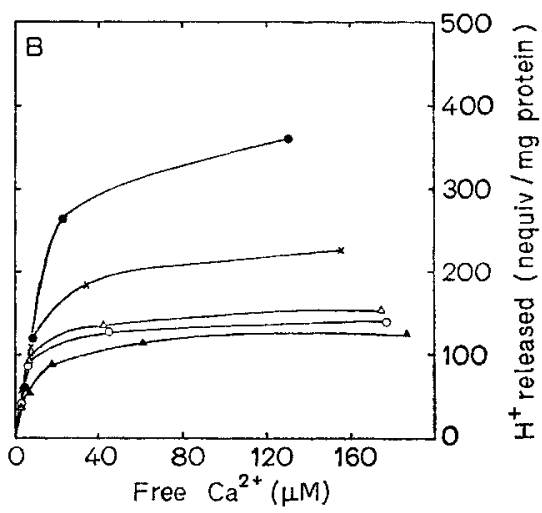

protein $/ \mathrm{ml}$ ) at $0-4{ }^{\circ} \mathrm{C}$. The experiments were carried out in $5 \mathrm{mg}$ reticulum protein suspended in $10 \mathrm{ml} 0.25 \mathrm{~m}$ sucrose at $22{ }^{\circ} \mathrm{C}$. The $\mathrm{pH}$ was maintained constant at a value of 7.0 by a Radiometer $\mathrm{pH}$ stat. (A) $\mathrm{Ca}^{2+}$ binding; (B) $\mathrm{H}^{+}$release. $O$, control; $X$, trypsin; $\triangle$, washed with $2.5^{\circ} \%$ albumin; - phospholipase $A ; \boldsymbol{\Delta}$, phospholipase $A$ and washed with $2.5 \%$ albumin

show that either enzyme greatly increases the passive binding of $\mathrm{Ca}^{2+}$ and the corresponding release of $\mathrm{H}^{+}$. This effect was not observed if the membranes treated with phospholipase A were subsequently washed with $2.5 \%$ albumin (Fig. $5 \mathrm{~A}$ ).

Treatment with phospholipase A (about $1 \mathrm{mg} /$ $100 \mathrm{mg}$ membrane protein) reduced the phosphorus content of the reticulum (mg $\mathrm{P} / \mathrm{mg}$ protein) to about $75 \%$ of the original value, whereas one washing with albumin solution of the treated membranes further 


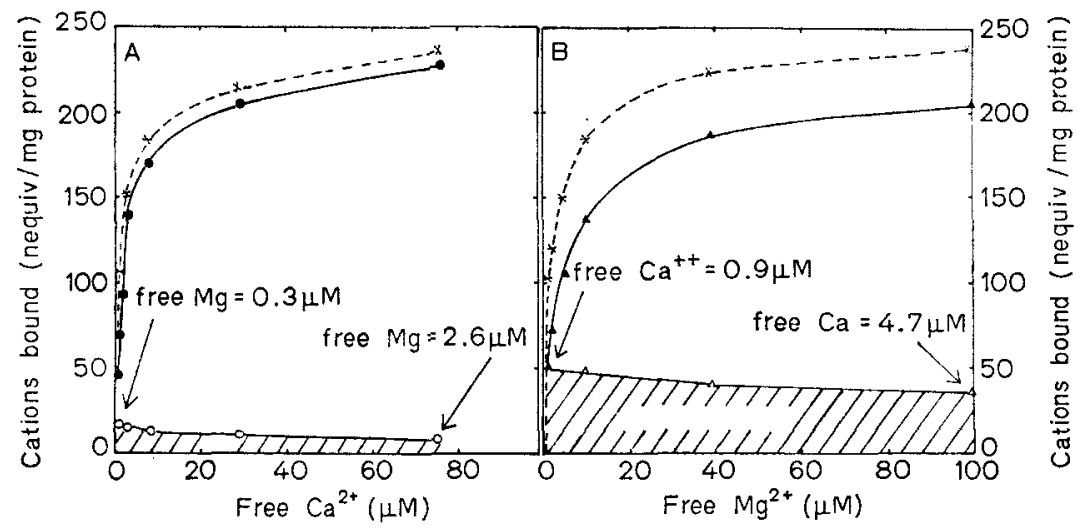

Fig.6. Passive binding of $\mathrm{Ca}^{2+}$ and $\mathrm{Mg}^{2+}$ by sarcoplasmic reticulum. Reticulum ( $5 \mathrm{mg}$ ) was suspended in $10 \mathrm{ml}$ of $0.25 \mathrm{M}$ sucrose at $22^{\circ} \mathrm{C}$ and the $\mathrm{pH}$ was maintained at a value of 7.0 with the aid of a Radiometer $\mathrm{pH}$ stat. The $\mathrm{Ca}^{2+}$ or $\mathrm{Mg}^{2+}$ were then added to the medium while the $\mathrm{pH}$ was maintained constant. After an equilibration period of $10 \mathrm{~min}$, the suspension was centrifuged, and the cations in the supernatant solu-

Table 1. Effects of phospholipase or trypsin on the phosphorus content of sarcoplasmic reticulum isolated from rabbit skeletal muscle, and the effect of washing the reticulum with albumin

\begin{tabular}{lc}
\hline Treatment & Phosphorus content \\
\hline & umol/mg protein \\
None & 0.60 \\
Washed with $2.5 \%$ albumin & 0.62 \\
Digested with phospholipase A & 0.45 \\
$\quad(1 \mathrm{mg} / 100 \mathrm{mg}$ reticulum) & \\
Digested with phospholipase A and & 0.14 \\
$\quad$ washed with $2.5 \%$ albumin & \\
Digested with trypsin & 0.87 \\
$\quad(1 \mathrm{mg} / 100 \mathrm{mg}$ reticulum) &
\end{tabular}

reduced this value to about $23 \%$ (Table 1 ). After washing with albumin, the $\mathrm{Ca}^{2+}$-binding capacity of the membranes was reduced to about $50 \%$ of the original value. Thus, it appears that the retention in the membranes of the products of hydrolysis of the phospholipids is essential for the increased $\mathrm{Ca}^{2+}$. binding capacity of the membranes caused by the treatment with phospholipase A (Fig. 5 A).

Treatment of the reticulum with trypsin $(1 \mathrm{mg} /$ $100 \mathrm{mg}$ of membrane protein) increased the phosphorus content of the membrane, if it is expressed in terms of $\mathrm{mg} \mathrm{P} / \mathrm{mg}$ protein, by about $15 \%$, and there was also an increase in the $\mathrm{Ca}^{2+}$-binding capacity (nequiv/mg protein) of the treated membranes (Fig.5 A). This apparent increase in $\mathrm{Ca}^{2+}$-binding may result because of the increase in the phospholipid content of the membrane material which is collected after the digestion with trypsin. tions and the pellets were analysed as described in the text. The amount of $\mathrm{KOH}$ delivered to maintain the $\mathrm{pH}$ value constant was used to calculate the $\mathrm{pH}^{+}$released by the reticulum membranes as a consequence of the addition of $\mathrm{Ca}^{2+}$ or $\mathrm{Mg}^{2+}$ to the medium. (A) Only $\mathrm{Ca}^{2++}$ was added to the medium. (B) only $\mathrm{Mg}^{2+}$ was added. $\bullet, \mathrm{Ca}^{2+} ; \times, \mathrm{Ca}^{2+}+\mathrm{Mg}^{2+}$; $\Delta, \mathrm{Mg}^{2+} ; \mathrm{O}$, 'intrinsic' $\mathrm{Mg}^{2+} ; \Delta$, "intrinsic" $\mathrm{Ca}^{2+}$

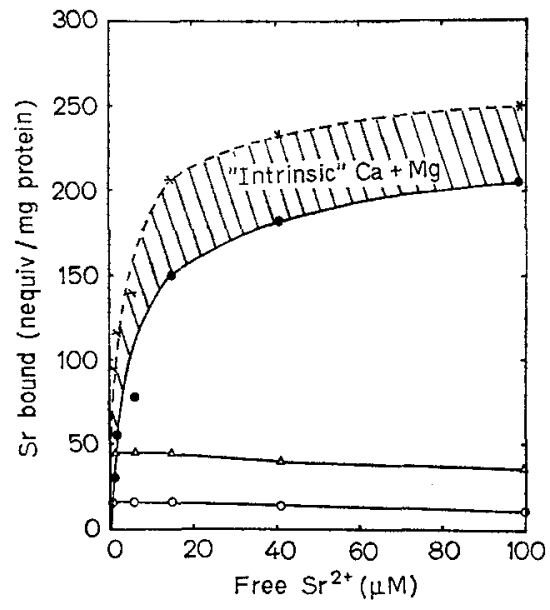

Fig. 7. Passive binding of $\mathrm{Sr}^{2+}$ and "intrinsic" $\mathrm{Ca}^{2+}$ and $\mathrm{Mg}^{2+}$ by sarcoplasmic reticulum. The experimental conditions were identical to those described in the legend of Fig.6, except that $\mathrm{Sr}^{2+}$ was added instead of the $\mathrm{Ca}^{2+}$ or $\mathrm{Mg}^{2+}$ utilized in the experiments whose results are depicted in Fig. 5. O, $\mathrm{Mg}^{2+}$; $\triangle, \mathrm{Ca}^{2+} ; \bullet, \mathrm{Sr}^{2+} ; \times, \mathrm{Sr}^{2+}+\mathrm{Ca}^{2+}+\mathrm{Mg}^{2+}$

\section{Relation between Passive Cation Binding and $\mathrm{H}^{+}$Release by Sarcoplasmic Reticulum}

Fig. 6 and 7 summarize the relation between the concentration of the free cations and their binding by the membrane. Since the isolated membranes normally contain about 50 equiv of $\mathrm{Ca}^{2+}$ and 15 nequiv of $\mathrm{Mg}^{2+}$ bound that can not be removed by washing repeatedly with $0.1 \mathrm{KCl}$, it is difficult to estimate the relative affinities and capacities of the membranes for the various cations. As indicated in Fig. 7 the "intrinsic" $\mathrm{Ca}^{2+}$ plus $\mathrm{Mg}^{2+}$ occupy a significant frac- 


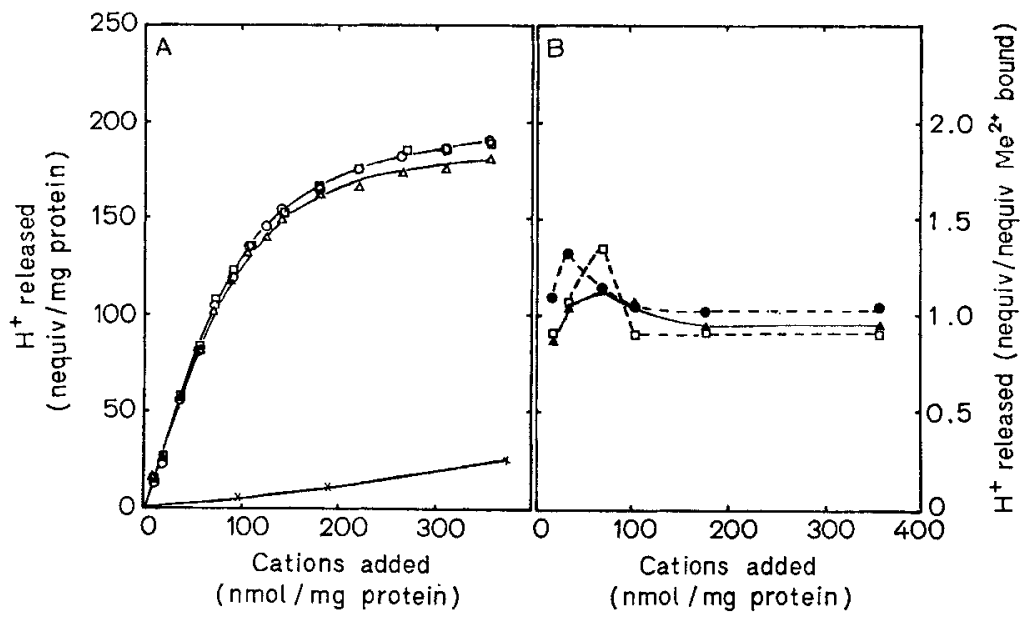

Fig. 8. Release of $\mathrm{H}^{+}$from sarcoplasmic reticulum by binding of $\mathrm{Ca}^{2+}, \mathrm{Mg}^{2+}, \mathrm{Sr}^{2+}$, and $\mathrm{K}^{+}$. The $\mathrm{H}^{+}$released at a $\mathrm{pH}$ value of 7.0 was measured with a Radiometer $\mathrm{pH}$ stat. The conditions for these experiments were those described for legends of

Fig. 6 and 7. In the computation of the ratio nequiv $\mathrm{H}^{+}$ released/nequiv $\mathrm{Ca}^{2+}$ bound (B), the "intrinsic" $\mathrm{Ca}^{2+}$ of the membranes was subtracted from the total bound $\mathrm{Ca}^{++}$ measured. $\triangle$, or $\Delta, \mathrm{Mg} ; \square, \mathrm{Sr} ; \mathrm{O}$, or $\bullet, \mathrm{Ca} ; \times, \mathrm{K}$

tion of the total number of binding sites available in the membranes. Thus, from the results depicted in Fig. 6 and 7, the affinity of the membranes for $\mathbf{S r}^{2+}$ or $\mathrm{Mg}^{2+}$ a priori appears to be lower than the affinity for $\mathrm{Ca}^{2+}$. However, this conclusion is not necessarily correct because of the inherent difficulty of measuring binding of one cation in the absence of other cations, since some $\mathrm{Ca}^{2+}$ and $\mathrm{Mg}^{2+}$ are released to the medium and compete for the binding sites with the other cations being studied. For example, in Fig. $6 \mathrm{~B}$ in which we attempted to measure the affinity of the membranes for $\mathrm{Mg}^{2+}$, we see that in addition to free $\mathrm{Mg}^{2+}$ in the medium we have a variation in the concentration of free $\mathrm{Ca}^{2+}$ from $0.9 \mu \mathrm{M}$ before $\mathrm{Mg}^{2+}$ was added to $4.7 \mu \mathrm{M}$ when the free $\mathrm{Mg}^{2+}$ was $100 \mu \mathrm{M}$. This increase in $\mathrm{Ca}^{2+}$ in the medium is caused by the release of bound $\mathrm{Ca}^{2+}$ as the $\mathrm{Mg}^{2+}$ is bound by the reticulum.

The total binding capacities $\left(\mathrm{Ca}^{2+}+\mathrm{Mg}^{2+}\right.$ or $\mathrm{Ca}^{2+}$ $+\mathrm{Mg}^{2+}+\mathrm{Sr}^{2+}$ ) are about the same in all cases, i.e. about 250 nequiv $/ \mathrm{mg}$ protein as determined from the data summarized in Fig. 6 and 7. In these experiments saturation was not reached, and previous experiments indicate that the maximal binding capacity of the reticular membranes at high concentration $(1-10 \mathrm{mM})$ of the free cations is of the order of 300-350 nequiv/mg protein [4].

In Fig. $8 \mathrm{~A}$, a plot of the $\mathrm{H}^{+}$released at various concentration of each of the cations indicated is shown. The same amount of $\mathrm{H}^{+}$is released for a given concentration of each of the three divalent cations tested. This suggests that probably there is little difference in the affinity of the reticulum membranes for the cations and that the apparent differences encountered in Fig. 6 and 7 reflect, in fact, the problems inherent in measuring the affini- ties as was discussed above. Potassium ions, which we showed previously to be bound much less strongly than the divalent cations, are here shown to be much less effective in displacing $\mathrm{H}^{+}$from the membranes of the reticulum.

The ratio of the $\mathrm{H}^{+}$released to cation bound is shown in Fig. 8B. When expressed in nequiv $\mathrm{H}^{+}$per nequiv cation bound, the ratio is nearly one at concentrations of the divalent cations in the medium above $100 \mathrm{nmol} / \mathrm{mg}$ protein. At the lower concentration of the cations, there is usually considerable variation in the ratio, but it appears to be higher than one. These ratios were calculated after subtracting the intrinsic $\mathrm{Ca}^{2+}$ or $\mathrm{Mg}^{2+}$ bound to the membranes and were determined at $\mathrm{pH}$ about 7.0. As will be seen later, the ratio depends very much on the $\mathrm{pH}$ of the medium.

The binding capacity of the membranes for $\mathrm{Zn}^{2+}$ is higher than that for $\mathrm{Ca}^{2+}, \mathrm{Mg}^{2+}$, or $\mathrm{Sr}^{2+}$ (Fig.11). In agreement with this it was found that the $\mathrm{H}^{+}$ release induced by $\mathrm{Zn}^{2+}$ is also more pronounced than that caused by the other divalent cations. Thus, the maximal $\mathrm{H}^{+}$release by $\mathrm{Zn}^{2}+$ is usually 300 to 400 nequiv/mg protein, whereas $\mathrm{Ca}^{2+}, \mathrm{Mg}^{2+}$ or $\mathrm{Sr}^{2+}$ release only about 150 nequiv/mg of protein at saturation. The evidence points to the existence in the membrane of binding sites that bind $\mathrm{Zn}^{2+}$, but not the other divalent cations, at least at the concentrations of cations utilized in these studies. Fig. 9 shows that after $\mathrm{Ca}^{2+}$, at a concentration of $500 \mu \mathrm{M}$, has caused nearly its maximal effect on the $\mathrm{H}^{+}$release, the addition of $\mathrm{Zn}^{2+}$ causes further release of $\mathrm{H}^{+}$, which suggests that $\mathrm{Zn}^{2}+$ interacts with dissociable sites that do not interact with $\mathrm{Ca}^{2+}$. However, $\mathrm{Zn}^{2+}$ also competes with $\mathrm{Ca}^{2+}$ for the sites which bind $\mathrm{Ca}^{2+}$ since $\mathrm{Zn}^{2+}$ displaces bound $\mathrm{Ca}^{2+}$ as is shown in Fig.9. 


\section{Binding of Cations \\ by Lipid-Free Sarcoplasmic Reticulum}

The phosphorus content of washed reticulum membranes is about $0.60 \mu \mathrm{mol} / \mathrm{mg}$ protein, whereas after extraction with acetone and ammonia [12] the phosphorus content is reduced to $0.061 \mu \mathrm{mol} / \mathrm{mg}$ protein. The binding capacity of the lipid-free membranes for $\mathrm{Ca}^{2+}, \mathrm{Mg}^{2+}, \mathrm{Sr}^{2+}$ and $\mathrm{Zn}^{2+}$ is lower than the binding capacity of the membrane before extracting the lipid. Fig.10 summarizes the effect of extracting the lipid on the binding of $\mathrm{Ca}^{2+}$ and $\mathrm{Mg}^{2+}$ and Fig.11 shows the effect on the binding of $\mathrm{Zn}^{2+}$.

The data show that the binding of $\mathrm{Ca}^{2+}$ or $\mathrm{Mg}^{2+}$ (and $\mathrm{Sr}^{2+}$, data not shown) is markedly depressed by the lipid extraction. At a concentration of free

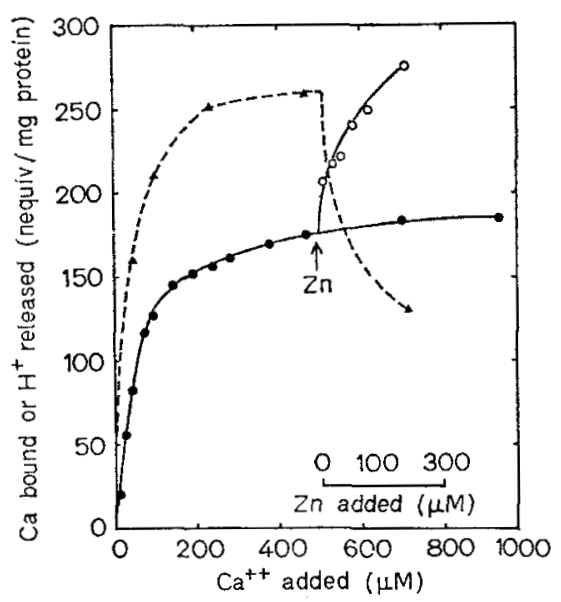

Fig. 9. Comparison of $\mathrm{Ca}^{2+}$ and $\mathrm{Zn}^{2+}$ with respect to the release of $\mathrm{H}^{+}$caused by these divalent cations. The passive binding of $\mathrm{Ca}^{2+}$ and the release of $\mathrm{H}^{+}$were measured as described in the legends of Fig. 6 and 8 . When the reticulum membranes were approaching saturation with respect to $\mathrm{Ca}^{2+}, \mathrm{Zn}^{2+}$ was added as indicated. $\Lambda$, Ca bound; $\bullet, \mathrm{H}^{+}$released; $\mathrm{O}, \mathrm{H}^{+}$released after addition of $\mathrm{Zn}$
$\mathrm{Ca}^{2+}$ or $\mathrm{Mg}^{2+}$ in the medium of $100 \mu \mathrm{M}$, the membranes before and after the lipid extraction approach saturation, however, the $\mathrm{Ca}^{2+}$ or $\mathrm{Mg}^{2+}$-binding capacity of the reticulum membranes after lipid extraction is lower by about $100-150$ nequiv per $\mathrm{mg}$ protein than before lipid extraction.

The depression in the $\mathrm{Zn}^{2+}$-binding caused by the lipid extraction is of the same order of magnitude of that observed for $\mathrm{Ca}^{2+}$ and $\mathrm{Mg}^{2+}$, but the $\mathrm{Zn}^{2+}$. binding capacity of the reticulum is about twice as high as its $\mathrm{Ca}^{2+}$ or $\mathrm{Mg}^{2+}$-binding capacity, so that even after the lipid extraction there are about 400 nequiv $\mathrm{Zn}^{2}+$ taken up per mg protein as compared to a maximum $\mathrm{Ca}^{2+}$ or $\mathrm{Mg}^{2+}$-binding of about 100 nequiv/mg protein (Fig. 10A and B).

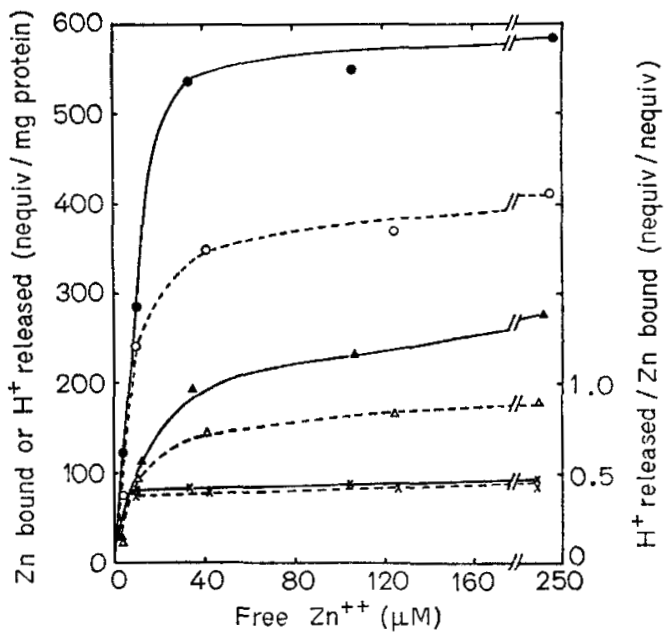

Fig. 11. Passive binding of $\mathrm{Zn}^{2+}$ and release of $\mathrm{H}^{+}$by sarcoplasmic reticulum before and after extraction of lipid with $90 \%$ acetone and ammonia. The experiments were carried out as described in the legend of Fig. 6, except that $\mathrm{Zn}^{2+}$ was added instead of $\mathrm{Ca}^{2+}$ or $\mathrm{Mg}^{2+}$. The results represented by dashed lines were carried out with reticulum whose lipid had been extracted with $90 \%$ acetone [12]. $\bullet, \mathrm{O}, \mathrm{Zn}$ bound; $\Delta, \Delta, \mathrm{H}^{+}$ released; $x, \mathrm{H}^{+}$released $/ \mathrm{Zn}^{2+}$ bound

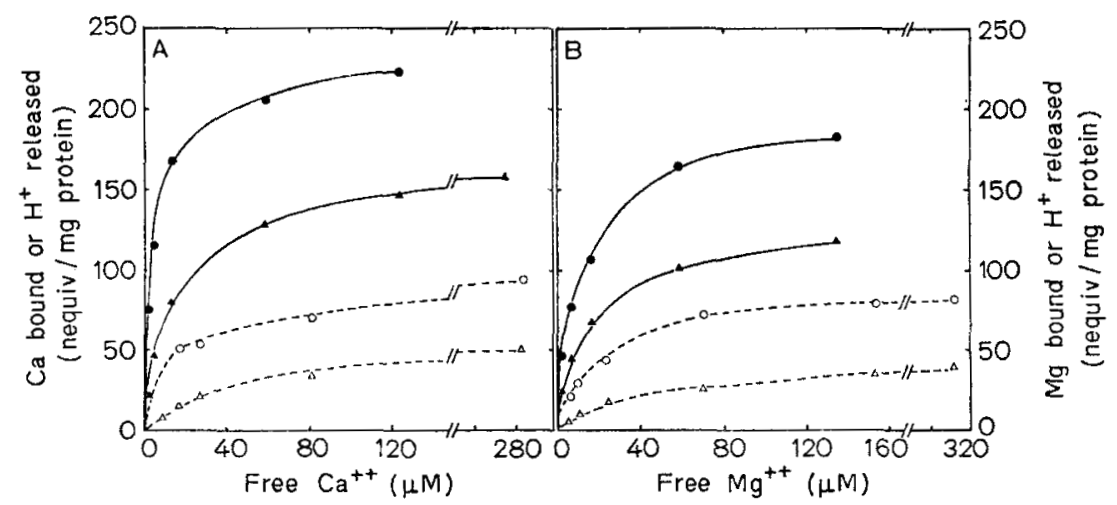

Fig. 10. Passive binding of $\mathrm{Ca}^{2+}$ or $\mathrm{Mg}^{2+}$ and release of $\mathrm{H}^{+}$by sarcoplasmic reticulum before and after extraction of lipid with $90 \%$ acetone and ammonia. The experiments were carried out as described in the legend of Fig. 6 except that in the cases represented by dashed lines, the lipid of the reticulum was first extracted with $90 \%$ acetone [12]. (A) $\mathrm{Ca}^{2+}$ binding $(\bullet, 0)$ and $\mathrm{H}^{+}$release $(\Delta, \Delta)$ induced by $\mathrm{Ca}^{2+}$; (B) $\mathrm{Mg}^{2+}$ binding $(\bullet, 0)$ and $\mathrm{H}^{+}$release $(\Delta, \Delta)$ induced by $\mathrm{Mg}^{2+}$ 
It appears, therefore, that about $60 \%$ of the $\mathrm{Zn}^{2+}$. binding, or about 400 nequiv/mg protein, is not bound to the lipids of the reticulum membrane since it still occurs after lipid extraction. In contrast, only about $40 \%$ of the maximal $\mathrm{Ca}^{2+}, \mathrm{Mg}^{2+}$ - and $\mathrm{Sr}^{2+}$-binding to isolated reticulum is observed after lipid extraction.

Fig. 12 shows the dependence of the binding of $\mathrm{Ca}^{2+}$ by the membranes before and after lipid extraction on the $p \mathrm{Ca}$ of the medium at $\mathrm{pH}$ 7.0. Both curves show an inflection point at a $p \mathrm{Ca}$ value of about 5, which suggests that the extraction of lipid does not affect the $\mathrm{Ca}^{2+}$-binding affinity of the membranes.

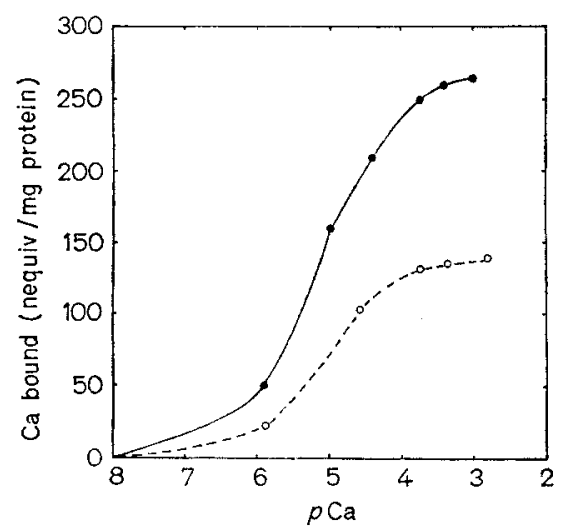

Fig.12. Comparison of the affinity and maximal binding capacity of the sarcoplasmic reticulum for $\mathrm{Ca}^{2+}$ before and after the lipid of reticulum is extracted with $90 \%$ acetone and ammonia. The passive binding of $\mathrm{Ca}^{2+}$ by $5 \mathrm{mg}$ of reticulum in $10 \mathrm{ml}$ of a $0.25 \mathrm{M}$ sucrose at $22^{\circ} \mathrm{C}, \mathrm{pH} 7.0$, was measured before $(\bullet)$ and after $(O)$ lipid extraction
It might be a mere coincidence that the membrane material remaining after lipid extraction has about the same affinity for $\mathrm{Ca}^{2+}$ as the lipoprotein complex before lipid extraction.

\section{Release of $\mathrm{H}^{+}$by Lipid-Free Sarcoplasmic Reticulum}

The passive binding of cations by sarcoplasmic reticulum causes a release of $\mathrm{H}^{+}$which is $\mathrm{pH}$-dependent (Fig. 13 and 14). There is an optimum $\mathrm{pH}$ value

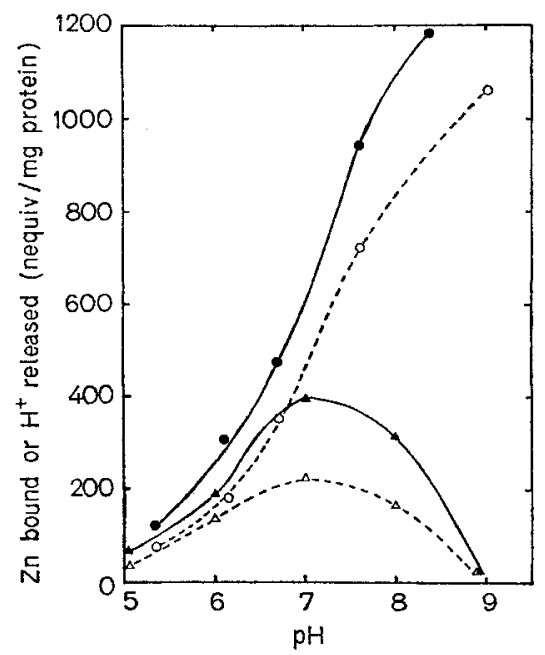

Fig. 14. Effect of $p H$ on the passive binding of $Z n^{2+}$ and on the release of $\mathrm{H}^{+}$by sarcoplasmic reticulum before $(\boldsymbol{\bullet}, \boldsymbol{\Delta})$ and after $(0, \Delta)$ its lipid was extracted with $90 \%$ acetone and ammonia. The experimental conditions were identical to those described in the legend of Fig. 12, except that $\mathrm{Zn}^{2+}(0.25 \mathrm{Mm})$, instead of $\mathrm{Ca}^{2+}$, was present in the medium. $\bullet, \mathrm{O}, \mathrm{Zn}$ bound; $\boldsymbol{\Delta}, \Delta, \mathrm{H}^{+}$ released

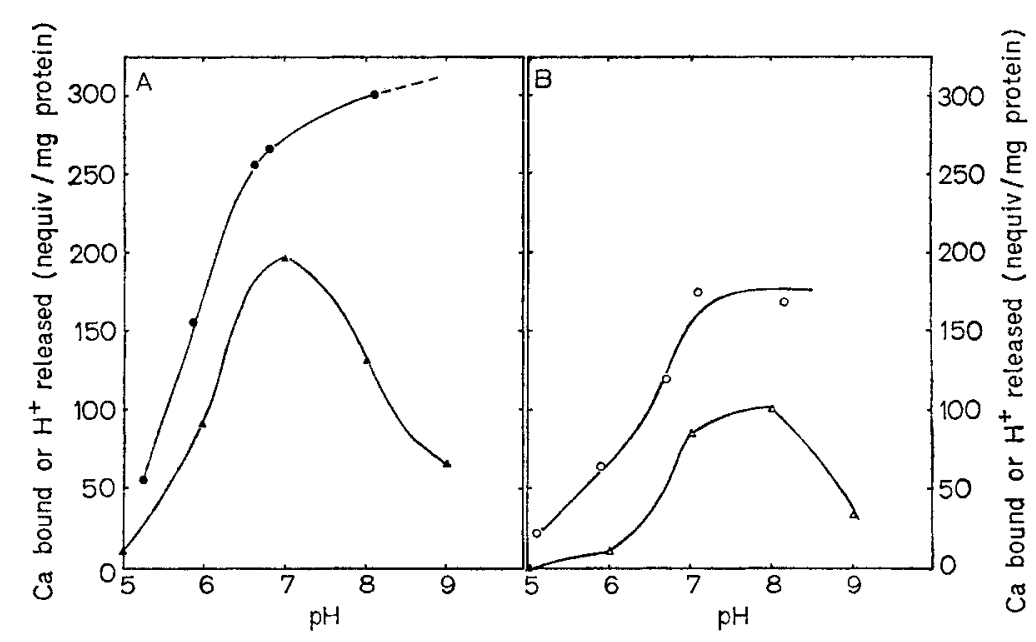

Fig. 13. Effect of $\mathrm{pH}$ on the passive binding of $\mathrm{Ca}^{2+}$ and on the release of $\mathrm{H}^{+}$by sarcoplasmic reticulum before and after its lipid was extracted with $90 \%$ acetone and ammonia. Sarcoplasmic reticulum before and after its lipid was extracted [12] was resuspended in $10 \mathrm{ml}$ of $0.25 \mathrm{M}$ sucrose solution at $22^{\circ} \mathrm{C}$ and the $\mathrm{pH}$ value of the medium was adjusted with either $\mathrm{KOH}$ or $\mathrm{HCl}$ with the aid of a Radiometer $\mathrm{pH}$ stat which maintained the $\mathrm{pH}$ constant at the desired value. Calcium

was added to the medium so that the final concentration was $0.28 \mathrm{mM}$. The $\mathrm{H}^{+}$release by the sarcoplasmic reticulum caused by the addition of the $\mathrm{Ca}^{2+}$ was automatically titrated. The suspension was then centrifuged and the $\mathrm{Ca}^{2+}$ binding was measured in the pellets as described in the text. (A) Results obtained with reticulum before lipid extraction; (B) results after lipid extraction. $\bullet, 0, \mathrm{Ca}^{2+}$ bound; $\Delta, \Delta, \mathrm{H}^{+}$ released 
for $\mathrm{H}^{+}$release at about 7.0 . The $\mathrm{pH}$ optimum is the same before and after the lipid extraction when $\mathrm{Zn}^{2+}$ is added to the medium, but appears to shift to a value of about 7.5 when the cation added to the medium is $\mathrm{Ca}^{2+}$. Furthermore, the $\mathrm{Ca}^{2+}$-binding reaches a plateau at a $\mathrm{pH}$ of $7.0-8.0$, whereas the binding of $\mathrm{Zn}^{2+}$ continues to increase as the $\mathrm{pH}$ of the medium is increased. These results were observed before and after the lipid had been extracted from the reticulum membranes (Fig. 13 and 14).

At $\mathrm{pH}$ values above $7.0-8.0$, there is a pronounced decrease in $\mathrm{H}^{+}$release by the membranes, probably because at these higher $\mathrm{pH}$ values all the onizable groups of the membranes have released their $\mathrm{H}^{+}$. Therefore, it is expected that those cations which are bound exclusively at these anionic sites of the membranes will be bound maximally at the $\mathrm{pH}$ values at which there is maximal release of $\mathrm{H}^{+}$and that no further binding should occur at higher pH values. This appears to be the case for $\mathrm{Ca}^{2+}$ (Fig.13) (and $\mathrm{Mg}^{2+}$ or $\mathrm{Sr}^{2+}$, data not shown), but is not the case for $\mathrm{Zn}^{2+}$ since the binding of this cation continues to increase even at the high $\mathrm{pH}$ values where there is decreased $\mathrm{H}^{+}$release (Fig. 14). Therefore, the increase in $\mathrm{pH}$ may have an effect on $\mathrm{Zn}^{2+}$-binding other than simply decreasing the competition of $\mathrm{H}^{+}$ with $\mathrm{Zn}^{2+}$ for the binding sites of the membranes.

The ratio of $\mathrm{H}^{+}$released to $\mathrm{Zn}^{2+}$ bound before and after lipid extraction is shown in Fig.11. The ratio is approximately 0.5 nequiv $\mathrm{H}^{+}$released/nequiv $\mathrm{Zn}^{2+}$ bound, as compared to 1.0 for the ratio $\mathrm{H}^{+}$ released $/ \mathrm{Ca}^{2+}$ bound (Fig. 8).

\section{DISCUSSION}

Our results indicate that the fraction of $\mathrm{Ca}^{2+}$ bound by the isolated sarcoplasmic reticulum can be released by $\mathrm{Zn}^{2+}, \mathrm{Cd}^{2+}$, phospholipases $\mathrm{A}$ and $\mathrm{C}$ or by trypsin. A significant fraction of the $\mathrm{Ca}^{2+}$ selectively bound in the presence of ATP remains bound for periods over $3 \mathrm{~h}$ after all ATP is hydrolys$\mathrm{ed}$, and as the $\mathrm{Ca}^{2+}$ is gradually released into the medium from which it was picked up, $\mathrm{Mg}^{2+}$ is taken up. If the medium contains $0.25 \mathrm{M}$ sucrose, the $\mathrm{Ca}^{2+}$ is not released. In detailed work reported earlier [4] we showed that the fraction of $\mathrm{Ca}^{2+}$ retained by the reticulum under the conditions of our experiments was bound at binding sites previously occupied by $\mathrm{Mg}^{2+}$ or other cations. Therefore, the results of the present studies indicate that bound $\mathrm{Ca}^{2+}$ can be mobilized from the membranes by agents (e.g. phospholipase and trypsin) whose effects on $\mathrm{Ca}^{2+}$ release have been assumed to be caused by an increase in the permeability of the membranes to $\mathrm{Ca}^{2+}$ so that free intravesicular $\mathrm{Ca}^{2+}$ would flow easily across the membrane $[6,9]$. Our studies do not exclude that such an effect may also occur, but they show that some of the $\mathrm{Ca}^{2}+$ released from sarcoplasmic reticulum comes from binding sites in the membranes. It is not known whether these binding sites are on the interior or exterior of the vesicles or both.

The observed increase in passive cation binding caused by phospholipase $A$, probably represents an exposure in the membranes of new anionic sites capable of binding cations. These anionic sites probably are present in the fatty acids and lysolecithin derived from the phospholipids since removal of these substances by washing the reticulum preparation with a $2.5 \%$ albumin solution depressed the cation binding capacity of the membranes to a value about $50 \%$ that of the original preparation (Fig. $5 \mathrm{~A}$ ). These results also suggest that the phospholipids of the membranes account for a relatively large cationbinding capacity of the membranes.

Recent results obtained by Fiehn and Migala [16] confirm that phospholipase A does increase the passive $\mathrm{Ca}^{2+}$-binding capacity of reticulum membranes at the higher free $\mathrm{Ca}^{2+}$ concentrations. These workers further studied whether vesicles which had been made leaky by one of various techniques bound $\mathrm{Ca}^{2+}$ in the presence of ATP and $\mathrm{Mg}^{2+}$ to the same extent as intact vesicles. They concluded that, since the disrupted vesicles invariably did not accumulate $\mathrm{Ca}^{2+}$ selectively, the function of ATP is in fact to promote transmembrane transport of $\mathrm{Ca}^{2}+$ rather than to induce selective binding of $\mathrm{Ca}^{2+}$ at membrane-binding sites as proposed by other workers $[4,5]$. We have obtained similar results in our laboratory, but have considered that this type of evidence is not conclusive in deciding between the two mechanisms of $\mathrm{Ca}^{2+}$ uptake. We do not know, for example, that in the process of making the membranes "leaky", we do not alter the structure of the membrane so that the $\mathrm{Ca}^{2+}$-binding selectivity can no longer be induced by ATP. Certainly, the present studies on the effect of phospholipase A on the binding capacity of the reticulum membranes show that the passive binding capacity of the membranes is affected, so that it is conceivable that the presumably more unstable selective $\mathrm{Ca}^{2+}$-binding affinity of the membranes may be damaged by agents which disrupted the vesicles.

The passive uptake of $\mathrm{Ca}^{2+}, \mathrm{Mg}^{2+}$ or $\mathrm{Sr}^{2+}$ by reticulum (Fig. 6 and 7 ) is a rapid process which occurs faster than we can measure, and the amount of the cation bound does not change significantly when the vesicles are ruptured by sonication or by other means [16, (unpublished observation)]. This suggests two possibilities. Firstly, if binding sites are located on both sides of the membranes of the vesicles, we must conclude that the membranes are very permeable to the cations which, therefore, have immediate access to all binding sites. Alternatively, the membrane are impermeable to the $\mathrm{Ca}^{2+}$ and disruption of the vesicles does not increase their passive binding capacity because all binding sites are located on the external 
side of the membranes. MacLennan and Wong [14] reported recently the isolation of a $\mathrm{Ca}^{2+}$-sequestering protein(calsequestrin) from sarcoplasmic reticulum which binds up to $970 \mathrm{nmol} \mathrm{Ca}{ }^{2+}$ per mg protein. The protein is solubilized quantitatively by deoxycholate, but is not released from sarcoplasmic reticulum by sonication or by extraction with $3.5 \mathrm{M} \mathrm{NaBr}$. On the basis of these findings, these workers suggest that the protein is hydrophobically bonded on the interior of the sarcoplasmic reticulum membranes. Thus, the $\mathrm{Ca}^{2+}$ would have to be transported into the interior of the vesicles before it would be bound $[4,14,15]$.

Following the hydrolysis of the phospholipids and the removal of the products (fatty acids and lysolecithin), the $\mathrm{Ca}^{2+}$-binding capacity of the reticulum membranes invariably decreased to about $50 \%$ of the original value (Fig.5). This suggests that calsequestrin probably is not the sole $\mathrm{Ca}^{2+}$-binding agent in reticulum. Furthermore, our findings are not in agreement with the results reported by Fiehn and Migala [16] who obtained no apparent alteration in $\mathrm{Ca}^{2+}$-binding capacity after treating the reticulum with phospholipase $A$ and removing the splitting products. This discrepancy arises because Fiehn and Migala studied the passive binding of $\mathrm{Ca}^{2+}$ in the presence of $5 \mathrm{mM} \mathrm{MgCl}, 40 \mathrm{mM} \mathrm{KCl}$ and $20 \mathrm{mM}$ histidine, whereas our medium contained only $0.25 \mathrm{M}$ sucrose. Consequently, we obtain a much higher binding, particularly at the lower free $\mathrm{Ca}^{2+}$ concentrations; for example at a $p \mathrm{Ca}$ of 4 about 200 nequiv $\mathrm{Ca}^{2+}$ are bound per mg protein, whereas they report a binding of 20-30 nequiv $\mathrm{Ca} / \mathrm{mg}$ protein. Apparently the $\mathrm{Mg}^{2+}$ and $\mathrm{K}^{+}$complete with the $\mathrm{Ca}^{2+}$ for the binding sites. Furthermore, as shown in Fig. 1, imidazole also depressed the $\mathrm{Ca}^{2+}$ binding by the reticulum. It appears, therefore, that because of the low value of $\mathrm{Ca}^{2+}$ uptake and the rather large scattering of the points, the effect on $\mathrm{Ca}^{2+}$ binding of depleting the membranes of phospholipids could not be detected by these investigators.

Cohen and Selinger [20] found that phospho. lipase $\mathrm{C}$ has no effect on passive $\mathrm{Ca}^{2+}$ binding by sarcoplasmic reticulum. However, the results reported by these workers show a maximal $\mathrm{Ca}^{2+}$-binding capacity of only $50 \mathrm{nmol} \mathrm{Ca}{ }^{2+}$ per $\mathrm{mg}$ protein as compared to $150-175 \mathrm{nmol} \mathrm{Ca}{ }^{2+}$ normally obtained in our laboratory. Trypsin has also been reported to inactivate the specific $\mathrm{Ca}^{2+}$ binder of sarcoplasmic reticulum accounting for about $5 \mathrm{nmol} \mathrm{Ca}{ }^{2+}$ per $\mathrm{mg}$ protein. This amount is too low to be detected in our experimental system in which we measured the effect of trypsin on the total $\mathrm{Ca}^{2+}$-binding capacity of sarcoplasmic reticulum. Under these conditions, trypsin appears to increase the $\mathrm{Ca}^{2+}$-binding capacity (Fig. 5A).

More recently, Chevallier and Butow ]21] reported the presence of two specific passive $\mathrm{Ca}^{2+-}$ binding sites with a total binding capacity of about $140 \mathrm{nmol}$ per $\mathrm{mg}$ protein, whereas the nonspecific $\mathrm{Ca}^{2+}$-binding capacity is reported to be $850 \mathrm{nmol}$ per mg protein. These values are much higher than have been found by other workers $[4,18,20]$, and cannot be accounted for by the endogenous $\mathrm{Ca}^{2+}$ which is only about 20-30 nmol per mg protein [4], although Chevallier and Butow [21] reported values of $500 \mathrm{nmol}$ per $\mathrm{mg}$ protein.

Further evidence that lipids, in addition to calsequestrin, are important in the passive uptake of $\mathrm{Ca}^{2+}$, as well as $\mathrm{Mg}^{2+}$ and $\mathrm{Zn}^{2+}$, was obtained with lipid-free membranes prepared by extracting the lipids with $90 \%$ acetone in the presence of ammonia [12]. Invariably, the depression of the binding of the cations caused by this treatment was accompanied by a parallel decrease in $\mathrm{H}^{+}$release (Fig. 10-13) which suggests that anionic sites exist both in the lipid and in the other chemical components of the membranes.

The anionic groups involved in the $\mathrm{Ca}^{2+}$ binding dissociate as the $\mathrm{pH}$ value of the medium is increased from about 5 to about 7 , which suggests that groups with $p K$ values in this range interact with $\mathrm{Ca}^{2+}$, whereas calsequestrin, which has a high capacity for $\mathrm{Ca}^{2+}$, has a high content of aspartic and glutamic acids whose dissociable groups have $p K$ values outside of this range. Our studies on the $\mathrm{pH}$-dependent binding of $\mathrm{Ca}^{2+}$ suggest that the imidazole group from proteins (possibly calsequestrin) and the phospholipid fraction of sarcoplasmic reticulum, probably play a role in passive $\mathrm{Ca}^{2+}$ binding by sarcoplasmic reticulum. We show in these studies that imidazole does in fact interact with $\mathrm{Ca}^{2+}$ (Fig. 1), and other studies [19] suggest a similar conclusion. It should be noted that MacLennan [14] also found that the binding of $\mathrm{Ca}^{2+}$ by calsequestrin falls sharply as the $\mathrm{pH}$ falls below 7.5. This would suggest that the carboxyl groups of the protein may not be important in $\mathrm{Ca}^{2+}$ binding, since alteration in the $\mathrm{pH}$ value in the range of neutral is not expected to affect the degree of dissociation of the carboxyl groups of glutamic and aspartic acids.

In view of the large capacity of the sarcoplasmic reticulum membranes for $\mathrm{Ca}^{2+}$, and considering that the $\mathrm{Ca}^{2+}$ taken up selectively in the presence of ATP and the absence of a precipitating agent is retained in the membranes mostly in the bound form [4], it is compelling to consider seriously the role that the bound $\mathrm{Ca}^{2+}$ may play in regulating the concentration of cytoplasmic free $\mathrm{Ca}^{2+}$. Furthermore, it is no longer expedient to disregard the large fraction of $\mathrm{Ca}^{2+}$ bound to the membranes when formulating the concept of the molecular mechanisms of $\mathrm{Ca}^{2+}$ translocation across the membrane of the sarcoplasmic reticulum.

The author expresses his gratitude to Dr A. Sandow for many perceptive observations and acknowledges the expert 
technical assistance rendered during the course of this work by Mr Julian Tsuang. This work was supported by grants from the Muscular Dystrophy Associations of America, NATO (Grant No. 388), the Portuguese Ministry of Education, and the Gulbenkian Foundation.

\section{REFERENCES}

1. Hasselbach, W. (1964) Progr. Biophys. Mol. Biol. 14, 167. 2. Hasselbach, W. \& Makinose, M. (1962) Biochem. Biophys. Res. Commun. 7, 132.

3. Weber, A. (1966) Curr. Top. Bioenergetics 1, 203.

4. Carvalho, A. P. \& Leo, B. (1967) J. Gen. Physiol. 50, 1327.

5. Ebashi, S. \& Endo, M. (968) Progr. Biophys. Mol. Biol. 18,123 .

6. Fiehn, W. \& Hasselbach, W. (1970) Eur. J. Biochem. 13, 510.

7. Fiehn, W. \& Hasselbach, W. (1969) Eur. J. Biochem. 9, 574.

8. Fairhurst, A. S. \& Hasselbach, W. (1970) Eur. J. Biochem. 13, 504 .

9. Inesi, G. \& Asai, H. (1968) Arch. Biochem. Biophys. 126, 469.

10. Johnson, P. N. \& Inesi, G. (1969) J. Pharmacol. Exp. Ther. 169,308 .
11. Carvalho, A. P. \& Mota, A. M. (1971) Arch. Biochem. Biophys. 142, 201.

12. Fleischer, S., Fleischer, B. \& Stoeckenius, W. (1967) J. Cell. Biol. 32, 193.

13. Hasselbach, W., Fiehn, W., Makinose, M. \& Migala, A.J. (1969) in The Molecular Basis of Membrane Function (Tosteson, D. C., ed.) p. 299, Prentice Hall Inc., Englewood Cliffs, New Jersey.

14. MacLennan, D. H. \& Wong, P.T.S. (1971) Proc. Nat. Acad. Sci. U.S.A. $68,1231$.

15. Weber, A., Herz, R. \& Reiss, I. (1966) Biochem. Z. 345, 329.

16. Fiehn, W. \& Migala, A. (1971) Eur. J. Biochem. 20, 245.

18. Carvalho, A. P. (1966) J. Cell Physiol. 67, 73.

19. Yu, B. P., Masoro, E. J. \& DeMartinis, F. D. (1967) Nature (London) 216, 822.

20. Cohen, A. \& Selinger, Z. (1969) Biochim. Biophys. Acta, $183,27$.

21. Chevallier, J. \& Butow, R. A. (1971) Biochemistry, 10, 2733.

\author{
A. P. Carvalho \\ Laboratório Zoológico, Universidade de Coimbra \\ Coimbra, Portugal
}

